\title{
Driven to Distraction: Turkish Diaspora Football Supporters, New Media and the Politics of Place-Making
}

\author{
by John McManus \\ University of Oxford
}

Sociological Research Online, 20 (2), 12

$<\mathrm{http}: / /$ www.socresonline.org.uk/20/2/12.html>

DOI: $10.5153 /$ sro.3588

Received: 15 Sep 2014 | Accepted: 12 Jan 2015 | Published: 31 May 2015

\begin{abstract}
This article explores how new media forms linked to the internet are feeding into the generation of community. It looks specifically at the place-making practices of a transnational group of football fans, European supporters of the Turkish club team Beşiktaş.I trace the mediations of two common football fan practices: the singing of chants and the display of banners. Adopting a multi-sited ethnographic approach, I track their circulation. While remaining part of the stadium experience, the chant and the banner have a prolonged life as digital objects. Fans combine them with new media practices, using them to expanding the array of places and means by which they can be Beşiktaş fans. The politics of building a transnational fan community is increasingly predicated on mediating between 'virtual' and 'actual' spaces. Success is measured through an individual's ability to intervene successfully on both the terrace and the Facebook page. This in turn requires a new form of interaction amongst fans, one based around a sense of distracted tactility. I conclude by suggesting the need to refigure the benchmarks by which we judge the affective relationships of fans. The sociology of sport can be refreshed through paying closer attention to the production of space, the materiality of internet media, and the sensate dimensions of the fan experience.
\end{abstract}

Keywords: New Media, Football, Diaspora, Internet, Place, Virtual

\section{Introduction}

1.1 It's a mild November night in Tel Aviv, Israel. I'm in the away section of the stadium of Maccabi Tel Aviv, a football team from the Israeli first division, cursing under my breath as I struggle to tie a knot strong enough to hold a banner taught. The football fan who roped me into helping him has finished his side and is growing impatient. The banner is in black and red spray paint and reads 'Çarş? Londra' (see Fig. 1).

1.2 Çarşı (from the Turkish for 'market place' or 'downtown') is the name of the main supporter's group for Beşiktaş, one of Turkey's top football teams. The 'A's in the banner are written as an anarchist A, reflecting the political bent of the grouping, who are involved in a diverse array of political and social actions in Turkey. Yet the fan in question does not live in Turkey. He's travelled to the game from London ('Londra' in Turkish). Indeed, if one were to look around the crowd of approximately 500, there are very few who actually have travelled from Turkey to be at the game. Most live in Tel Aviv. Many are part of an approximately 6 million strong Turkishspeaking diaspora community in Europe. They are here to watch Beşiktaş take on Maccabi Tel Aviv in the Europa League, a European-wide football competition that takes place annually.

Nearly all in the crowd are dressed in black and white - the colours of Beşiktaş - but there are a handful of fans in the red of the Turkish national team, and even a few dressed in the jerseys of Beşiktaş's local rivals, Fenerbahçe and Galatasaray. There have been some scuffles between the fans. At the front of the stand, one individual has hoisted himself onto the advertising board with his back to the pitch. He's conducting the crowd in a chant denigrating all those who are not fans of Beşiktaş.

'Not bad, ey?' says the fan to me in English while taking a picture of his handiwork with his phone. We push our way into the middle of the crowd. Five minutes later I am distracted by my phone vibrating. It is a notification from Facebook - I've been tagged $[1]$ in a post of the banner. At half time, I look at the post properly and see there are already a few comments in Turkish underneath. I recognise some of the people commenting, others I do not. I put my phone away and turn my attention back to the crowd... 


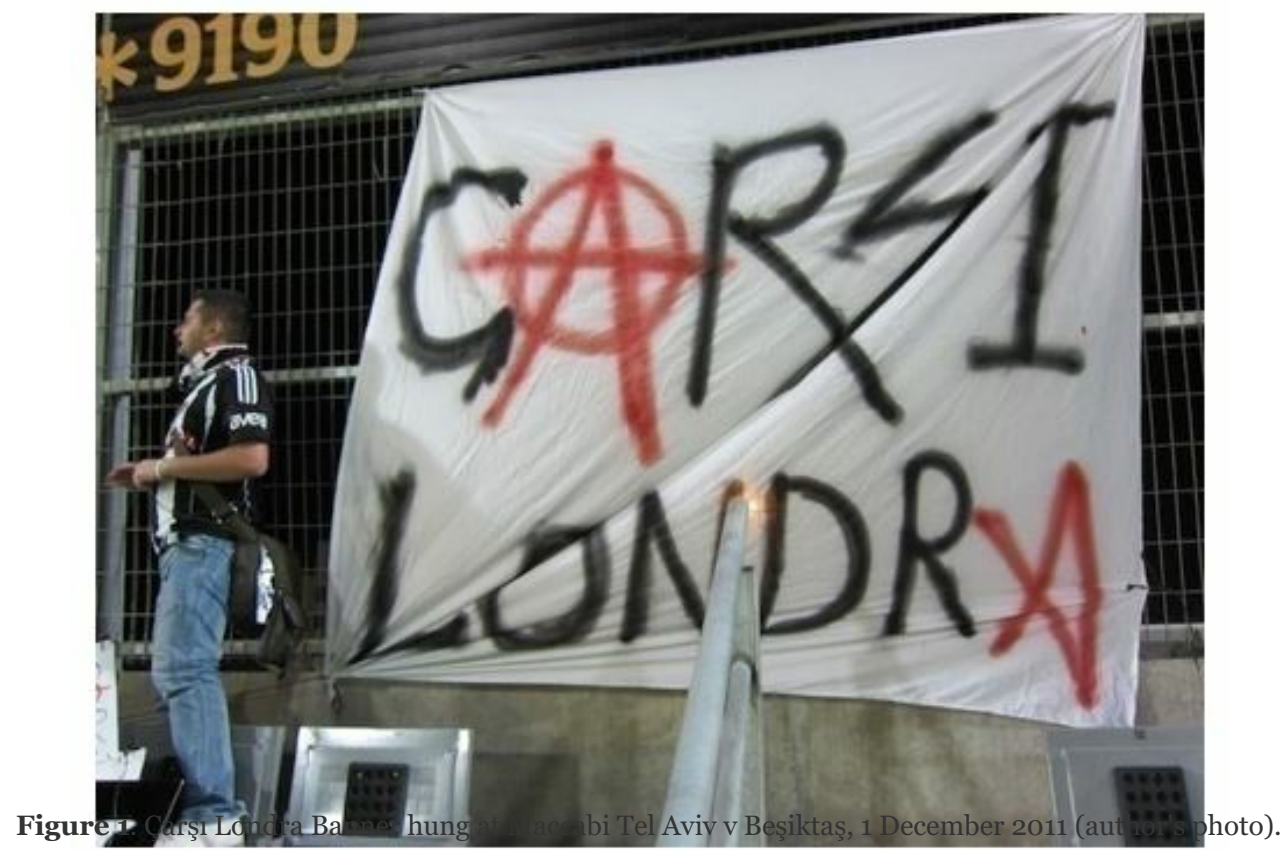

1.5 Elements of this scene will probably be familiar to any attendee of a recent professional football match. Around most football stadiums, 'traditional' activities through which fans show their support - waving banners, wearing team shirts and singing - are rubbing shoulders with newer processes such as taking photos on mobile phones and posting them on social networking sites. Many of these new developments allow those who are not physically present to take part in the practice at the same time as those at the game. As such, these practices play an important role in binding those who are further removed from events to the 'imagined community' of supporters (Anderson 2006).

1.6 In this article, I look as the creation of one such community of supporters at a distance: Europe-based fans of the Turkish club team Beşiktaş. While the home of Beşiktaş is in Istanbul, there exist millions of fans in Western Europe, mostly from the large Turkish-speaking diaspora communities that have been established over the past half century.[2]

1.7 My focus is on how internet media impact upon the generation of a European Beşiktaş fan community. I investigate two traditional fan practices - the singing of chants and display of banners - following both as they become intermeshed with new media use. In doing so, I build on the work of those in material culture studies interested in the life-cycle of objects (Appadurai 1986; Lash \& Lury 2007b; Miller 2005) and add to the endeavours of a growing group of scholars for whom internet media are a prime object of study (Boellstorff 2008; Coleman 2012; Miller 2011).[3]

1.8 I argue that the amalgamation of physical item or oral chant with internet media is producing differing conceptions of footballing space - namely, a more explicit notion of virtual spaces. Virtual space, I suggest, is produced dialectically, out of an opposition with 'actual' space; social processes like fandom emerge through how individuals and communities mediate between the virtual and the actual, between determined and potential notions of how to be fans. As will become clear, the process can be highly political.[4]

1.9 Exploring the multidimensional nature of football support requires a multi-sited methodology (Marcus 1995). The ethnographic material emerges from both 'physical' fieldwork - in bars and at Beşiktaş matches in European competition - and 'virtual' ethnography on messageboards and social media. Consequently, the findings stand in contrast to much existing work on internet-mediated football fandom, which focuses disproportionately on the online realm (see Gibbons \& Dixon 2010; Rowe et al. 2010; Ruddock et al. 2010).

1.10 I suggest the production of virtual spaces is not through passive absorption but tactile doing. Media are increasingly functioning as objects, dealt with not through interpretation but operation, be it the swipe of a finger or the prod of a mouse. It is also an activity born out of distraction. Contemporary media practices encourage engagement in absented passing rather than studied contemplation. This realisation has a knock-on for ideas of human behaviour, socialisation and the generation of communities. It suggests the most salient characteristic of Beşiktaş places - perhaps contemporary football space more widely - to be that they are distracting places, or perhaps 'places of distraction'.

\section{Placing the research}

2.1 The article brings together literature from a number of debates. The first surrounds the production and mediation of space. While a physical space may exist, as Henri Lefebvre notes, 'space considered in isolation is an empty abstraction' (Lefebvre 1991: 12). Space needs to be experienced in order to be registered. For Lefebvre, the 
task of the researcher is to 'immediately indicate what occupies that space and how it does so'. Working from a practice-theory perspective, I argue that 'how' Beşiktaş fans occupy certain spaces is not through processes of interpreting but of doing (Bourdieu 1993; Ortner 2006; Thrift 2008). Yet it is not just one-off activities but repetitive doing. In line with Shaun Moores, I view the recursive element of these practices as their crucial characteristic. Repetitive, habitual practices generate attachments and these attachments bind people to their material environment (Moores 2012: 27). Football provides ample opportunity for supporting practices to be repeated: games are scheduled at weekly intervals; coverage in the media is renewed daily, sometimes hourly; one can return to football continuously in order to reaffirm one's connection. Football consumption, then, is itself a practice of mediation, a communication tool helping people bond and bind with other individuals.

The nouns 'habitation' and 'dwelling' are associated most commonly with being still, yet as demonstrated by the fan taking the photograph of the banner with his phone, spaces associated with football support are increasingly being experienced through mobile media practices. ${ }^{[5]}$ Second, then, is to consider the extent to which we need a 'new mobilities paradigm' to account for practices such as those undertaken by Beşiktaş fans (Sheller \& Urry 2006). In media studies, work on mobility has mostly been directed towards GPS systems (DeNicola 2012) or mobile phones (Ito et al. 2005; Ling \& Donner 2009). What is less well explored, due to its recent emergence, is what happens when a phone becomes a computer, also known as a smartphone.[6] The focus on internet media can subsequently be defined further: the article explores the effect of smartphoneaccessed internet media on the creation of fan communities.

The last decade has seen literature emerge within the sociology of sport around diaspora and transnational fan communities (see Giulianotti \& Robertson 2009; Millward 2011). While covering large swathes of the globe and many different cultures, the literature remains heavily focused on the English Premier League (Ben Porat 2000; Hognestad 2006, 2009). Taking my lead from Giuliannoti and Robertson's study of the Scottish diaspora (Giulianotti \& Robertson 2006, 2007), I suggest the dynamics of transnational fandom can be greatly enriched by turning to supporters associated with less prominent leagues and countries, not least by helping build up a more robust framework for comparative analysis.

2.4 Finally, my material culture orientation is prompted by the large importance Beşiktaş supporters placed on objects. Interlocutors would direct my attention towards fan videos of chanting in the streets; at games, disputes would break out over how fans should wave their scarves and flags. The sociological conversation surrounding transnational or diaspora sports groups can be refreshed and expanded by privileging these materialities, exploring how they are being used to mediate social relations, express power, or realise particular conceptions of the self.

The article proceeds by tracing the mediations of two common practices of football fandom: the singing and listening of chants and the production and display of banners. The concern in each case is following these items through space and time, logging how they are used by fans to generate Beşiktaş places. The starting point is the stadium. Tracking the items, however, reveals that the majority of Beşiktaş fans are more comfortable and experienced with constructing fandom in virtual spaces.

The chant and the banner become digitised: fans combine them with new media practices, expanding the array of places and means by which to be fans. The production of these virtual spaces is not through the representation of physical items. Media, like culture more widely, has become materialised - 'thingified' (Lash and Lury 2007) - dealt with not through symbolism and interpretation but operation.

2.7 The final section looks at how this operation is based around a renewed sense of distracted tactility. If the overall characteristic of these new virtual spaces is as 'places of distraction', then inhabitation in these realms means fan communities are coloured by similar states of mind. Accordingly, perhaps the transnational and 'local' fan are not as far apart as imagined, both united in the distracted dance of occupying simultaneously both virtual and actual footballing space.

\section{Chants}

3.1 For European Beşiktaş fans, the best opportunity to be present at a Beşiktaş match is when the side play away in Europe; that is, when they play against a team from another European nation. On such occasions, the collective singing and chanting of Beşiktaş fans builds a sense of community through its locative dimension. One chant directed at fans for rival Turkish clubs goes, 'you can't become a Beşiktaş fan, you're born a Beşiktaş fan. All those who aren't Beşiktaş fans are sons of bitches' (Beşiktaşlı olunmaz Beşiktaşh doğulur, Beşiktaşlı olmayanlar orospu çocuğudur)

3.2 Yet not all fans agree with this stance. Many people view an away game in Europe as a Turkish event first and a Beşiktaş event second. Assorted fans will attend the game with their Turkish-speaking friends and relatives regardless of their team affiliation. They feel that this aggressive exclusion of opposition fans - calling them sons of bitches - is shameful. At a game between Stoke City and Beşiktaş in Stoke-on-Trent, England in September 2011, the aforementioned chant is sung by a hardcore Beşiktaş fan group outside the ground. It gets boos from elsewhere and other fans respond with chants of 'Türkiye' (Turkey). This prompts the fanatical Beşiktaş fan group to start another chant: 


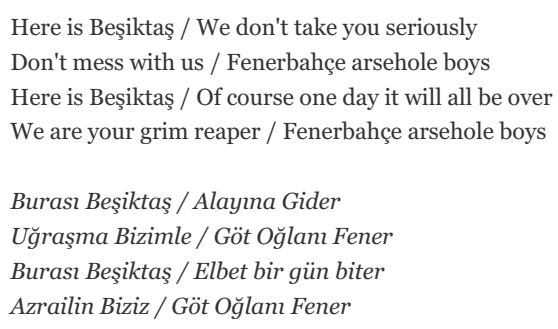

In this chant, the idea of place is more explicit: 'here' is Beşiktaş. In the response of some in the crowd with 'Turkey', we see how 'Turkey' and 'Beşiktaş' are being manoeuvred into diametrically opposed positions. The names become terms taken up by either side to argue two different conceptions - one more inclusive, the other exclusivist - of who should be attending Beşiktaş matches.

A German member of the hardcore Beşiktaş fan group who is fluent in English pleads with the nearest policeman to not allow fans of opposing teams into the stand: 'if somebody wants to go in, [say] please take your shirt off, yeah? You can say 'for your own safety'...we don't want any trouble but...nobody can guarantee that somebody doesn't freak out and goes and hits him'. But the policeman moves barely five metres before he's accosted by another Beşiktaş fan arguing the exact opposite. This fan, in a native London accent, exclaims: 'these guys are from Berlin and what they are arguing, it is not right'. He explains how there are Turks from 'near here', who live here. He continues, 'They come [to the game] when a Turkish team come down so what they asking, itit's wrong.'

Place-making now is being couched in terms of Western European nation states: those guys are 'from Berlin' (i.e. not British), coming over 'here' (Britain) and suggesting something that is wrong. They are stopping people who are 'from here' from doing what they want to do. No one is mentioning it explicitly but it seems as if the official nationalities of individuals are structuring the conception of the space and who has the right to act within it. The 'English' fan sees the hardcore group as German first and Turkish second. Swilling through the crowd, then, are multiple notions of 'national space'. The concatenation of differing nationalities present means no stable binary can be constructed. In the flesh, chants can have a strong locative element, used to map environments for football support and draw the boundaries of exclusion and inclusion.

\section{iPhone chants}

A fan in North London listens to Beşiktaş chants on repeat while at work. He works the night shift at one of the large supermarket chains in the UK, replenishing the stock between 10pm and 6am. One Saturday, while sitting in a bar in North London watching a game, he takes out his phone and plays a chant for me that he had downloaded from somewhere. He explains that, one evening at work, he just listened to this same song for the entire shift.

As the vignette illustrates, football chants are not just collective forms of place-making. Fans record or download chants in order to play them back on occasions when they are alone. At such moments the chant has become 'mediatized' by the smartphone, absorbed into the material framework of mobile phone data networks, bytes and amplifiers (Lash and Lury 2007). In this environment the chant remains a strategy of place-making, yet one that operates along different criteria, chief among which is managing one's presence in an urban environment.

Mizuko Ito et al. argue that music devices are one of a host of activities that people engage in to 'cocoon' themselves from 'engagement with the physical location and co-present others'. There is a temporal dimension to this activity: cocoons 'function as mechanisms for "filling" or "killing" in-between time when people are inhabiting or moving through places within where they are not interested in fully engaging' (Ito et al. 2009: 74). This is certainly the case with the fan who listens to chants at work. He expresses to me often how boring his job is and how little he cares for it. He is continually inventing strategies to distract himself, such as sneaking off for a nap when his supervisor is preoccupied. Listening to football chants is another strategy to 'kill' the time and monotony of stacking shelves throughout the night.

Yet if, as explained before, we work from formation of place as 'experiential... a practical and emotional accomplishment' (Moores 2012: 52), then a question is raised as to where we should locate this Beşiktaş fan: in the Enfield branch of Morrison's or in a Beşiktaş song? To paraphrase Emanuel Schegloff, there seem to be two 'theres' there: the physical location and the location generated by the media (quoted in Moores 2012: 20). Various scholars have argued that media use contains an inherent 'doubling' or 'pluralisation' of place. Mobile media technologies make this process more explicit, as they increase the range of physical locations a user can occupy, yet the same process occurs when watching television or browsing the internet at home (Farman 2012: 39; Moores 2012; Scannell 1996). sometimes labelled 'virtual'. The use of the term virtual in both computing language and common terms such as 'virtual reality' usually connotes distinctiveness from normal social life. Yet 'virtual' practices, such as checking Facebook or listening to music while at work, are, for many, archetypal parts of 'normal' life. I wish to refashion the term so that it is understood less as something not physically existing and more in terms of potentiality. In 
colloquial English someone can say 'she's virtually my sister' to refer to a close friend. It means she is not formally a sister, but is so in essence or effect (Boellstorff 2008: 19). There is a gap between the actual (she is not a blood relation) and the experience (we behave to each other as if we're blood relations). For Mazzaralla the mediation of this gap is social process. We make sense of the world through mediating between 'the virtual and the actual', which can also be recast as a mediation between 'potentiality' and 'determination' (Mazzarella 2004: $348)^{[7]}$.

Indeed, as Tom Boellstorff notes, it is the unbridgeability of the gap which is its important character: '"Virtual" connotes approaching the actual without arriving there' (2008: 19, emphasis in original). Despite the prognostications of certain science fiction films or alarmist media reports, it is impossible for the virtual and actual to collapse into each other. We cannot live our entire lives in a virtual space - we need to eat, or go to the toilet for instance. Likewise, even if we never watch television or browse the internet we cannot stop ourselves from visualising other places in the form of daydreams, hopes and aspirations. Virtual spaces do not supplant actual spaces. The relationship is one of an indelible dialectic sitting at the heart of our experience of everyday life. We are always in multiple spaces: daydreaming at the office desk, imagining a friend's routine on the other side of the world or becoming engrossed in a television drama. Media just make this experience all the more obvious.

If people are in multiple spaces, distributing themselves across many realms, this should unsettle the easy categorisation of spaces as private or public. When discussing the Walkman, Iain Chambers suggests that 'the ingression of such a privatised habitat in public spaces is a disturbing act' (Chambers 1994: 52). Yet for my research participants, most of whom have no concept of a pre-Walkman world, failing to drawing attention to the fact that one is in multiple spaces - physically here but aurally or visually elsewhere - is the disturbing, provocative act. It's not that 'private' sound devices challenge a 'public' conception of space. If the default is cocooning, then the public field is better conceptualised as comprising congeries of private cocoons.

This realisation has a knock-on effect for the politics of calling and assembling people. Chambers could argue in 1994 that the Walkman 'confer[s]... a different sense on the polis. In producing a different sense of space and time, it participates in rewriting the conditions of representation' (Ibid 1994: 52). Yet in the $21^{\text {st }}$ century where the use of the smartphone-as-music player is near ubiquitous, the pick-and-mix, bricolage mode of participation that Chambers heralds is no longer unsettling but expected.

4.8 The politics of the digitized chant seem more conservative and routinized: football chants are recorded in music studios, their mash-up or collage actively encouraged through packaging and sale as individual songs; cocooning is endorsed through ever more variety of headphones equipped with the latest sound cancellation technology. Caught up in the intensity of this process - of being both 'here' and 'there' - users can be said to be distracted from occupying anywhere fully; indeed there seems the need for revising concepts of habitation to longer express fixity but instead what Nigel Thrift describes as dwelling in the 'onflow of information in motion' (Thrift 2011: 16).

4.9 Exploring the different environments in which Beşiktaş chants are produced and consumed reveals the versatility of their role in the fan experience. In the flesh, chants are sung to draw the collective boundaries of the fan community. Virtually, they can be the product of individual proclivity, used to manage one's presence in the everyday environment, kill time in transit or cocoon from work.

4.10 The process is highly political, but perhaps not in the way first assumed. At games, chants mediate the identity politics of diaspora communities. Wrapped up in the lyrics and performance is the uneasy, and ultimately irresolvable, debate over the warp and weft of Turkish, English, German and Beşiktaş associations which should be performed and which omitted? In the earbuds of the music player the chant takes on a more laissez-faire hue. Packaged and consumed as mp3 or music video, it accords to the consumption-defined autonomy to construct one's own environment as one sees fit. The chant becomes a more affordable corollary to those larger-scale attempts at building a cocoon in the urban environment, such as the gated community or the sports utility vehicle.[8]

\section{Banners}

5.1 Fans attend Beşiktaş matches most commonly as part of a small group, comprised usually of a mix of relatives and friends. Sometimes these groupings like to signal who they are to others. The most common manner in which this is done is through producing a banner that can be held aloft or attached to the stand.

5.2 In order to display a banner in a stadium, fans must first pass a security check where club officials will frisk them, check bags and require banners to be shown. Often these authorities have no prior experience of hosting Turkish away fans and are ill equipped to discern the fine-grain cultural particularities of Turkish fan support in order to judge which items to allow and which to deny. To try and ameliorate this process, the Beşiktaş football team travel with a handful of security advisors employed by the club. Middle-aged men dressed in a uniform of suit and earpiece, these advisors supply the stadium authorities with their cultural knowledge to help regulate the Beşiktaş crowd. 
At the match in Tel Aviv described at the start of the article, the Israeli ground staff were spooked by the anarchist 'A' in the Çarşı Londra banner. We were told to wait while they ran the banner past the Turkish security advisors to check for 'political messages'. The anarchist A has become part of the iconography of the Çarşı fan club. Its presence on the banner is usually not an attempt to make a political statement, merely to replicate the stylisation of banners in Turkey. In this case, the Beşiktaş staff act as successful cultural translators, confirming to the Israeli security staff that the banner harbours no subversive or offensive message, and we are subsequently allowed to take it through. Not all fans are so lucky, however. One forbidden banner stated, 'We Beşiktaş fans are against war!' The use of the word 'war' seemed to be too risqué for authorities at a time of tense Israeli-Turkish relations, despite the fact it was being mentioned in a negative context.[9] Our group is made to unfurl another banner, about 20 feet long that reads 'different countries, same love' (üIke farklı aşk aymı). The Israeli security person says to his Beşiktaş counterpart: 'I will not allow it because it's flammable'. The objection to the banners has shifted from the message to its composition. The banner's materiality - its 'thingness' - now becomes the sticking point, contravening health and safety laws. The uneasy mediation of the eşiktaş security staff becomes apparent. A minute ago the official lined up with the Israeli staff in preventing a banner mentioning war from being brought in. Now he's on the side of the Turkish fan arguing for entry: 'it won't flame [sic] because they're going to put it in front of their seats. It's not gonna [be] among the people. It's gonna be separate'. This intervention works, the Israeli official relents and the banner is allowed through.

If all these obstacles are surmounted and the banner makes it to the terrace, one further constraint remains. European Beşiktaş fans often judge their behaviour in the space of the stadium in relation to supporters at home games in Turkey. European supporters try to recreate practices that they have witnessed on satellite TV, come across when browsing online or sometimes experienced in the flesh, perhaps failing to recognise that most of the behaviour in Turkey can only arise because it is a home place over which fans have an unique amount of control and familiarity. A chant which European Beşiktaş fans have witnessed rippling round Beşiktaş's 35,00o capacity home stadium, or a banner that is reported all over the Turkish press can fall flat when attempted by 500 people at an away match in Israel. When it does, it can generate much anger and angst. Alongside physical interventions, the mediated image of 'what fans should be doing' acts as a constraint on attempts to inhabit the space as authentic Beşiktaş supporters.

\section{Moving Banners}

6.1 The deployment of a banner in a stadium is only one stage in its typical 'life-cycle' (Gell 1998). One common move a banner makes is from a stadium to a social networking website. This is mostly achieved via the photographic image. As Martin Hand has noted, the falling cost and ease of use of digital photography means that in the West the photographing and recording of events has become 'ubiquitous' (Hand 2012).

At the game in Tel Aviv, one fan had produced a banner that read 'Çarşı Israel'. As with the 'Çarşı

Londra' banner, it was explicitly modelled on the style and name of the group in Turkey. At the end of the game, I witnessed other Beşiktaş fans ask its creator if they could have their photo taken holding it. The fan in question obliged (Fig. 2). The banner seems to be acting as a prop legitimising the more occasional fan's attendance at the game, piggybacking off an image of the 'authentic' or 'hardcore' fan.

6.3 The process seems to echo what Scott Lash and Celia Lury describe as the 'thingification of media'. They argue that in our contemporary 'global culture industry', media are no longer representations but things. When this happens, 'we enter a world of operationality, a world not of interpretation but of navigation. We do not 'read' them so much as 'do' them...or do with them' (Lash \& Lury 2007b: 8). Critically, this process is not limited to banners. In November 2012 at a basketball match in Lithuania between Lietuvos Rytas and Beşiktaş, a girl emerges from the Lietuvos supporters and interposes herself amongst a group of Beşiktaş fans having their photograph taken. The girl makes her Lietuvos friend take a photograph of her in the middle of the Beşiktaş fans, smiling with her thumbs up (Fig. 3). Here we go one stage further: the fans themselves have been 'thingified', categorised as media in the eyes of locals and used as a backdrop to construct a particular narrative about one's participation in the event.

6.4 Lash and Lury's use of the word 'navigation' prompt questions of space and landscape. One thing that fans are 'doing with' banners, then, is landscaping the environments that they are occupying. A photograph is a powerful tool in this process as it allows fans to marshal events into a particular frame. In the taking of a picture, fans freeze a specific arrangement of time and space. The photograph becomes materialised as a discrete point, a waymark that is used to position oneself in the wider topographies of the event and of Beşiktaş fandom more widely. 


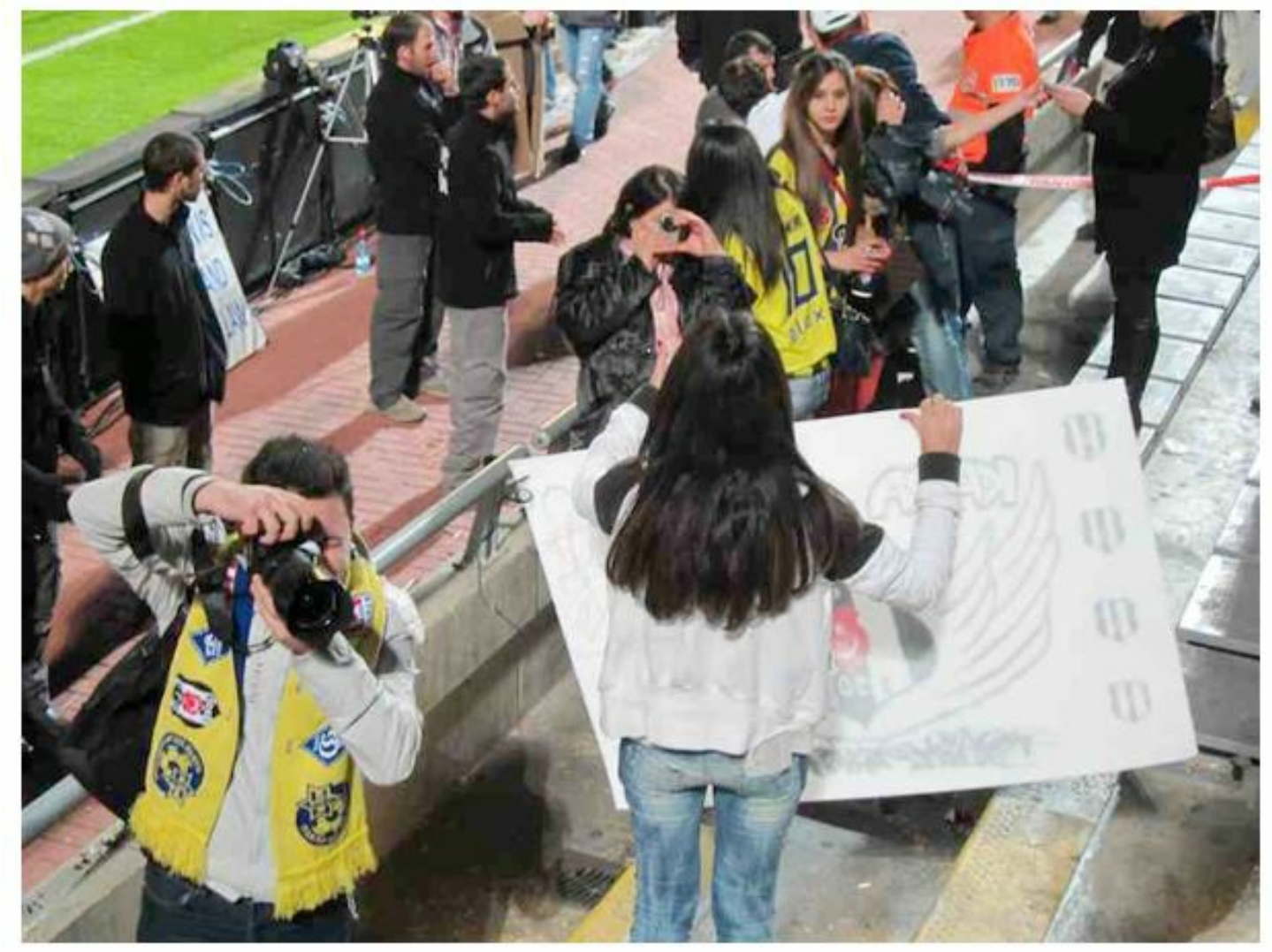

Figure 2. Beşiktaş fan posing with Çarşı Israel banner at Maccabi Tel Aviv v Beşiktaş, 1 December 2011 (author's photo). 


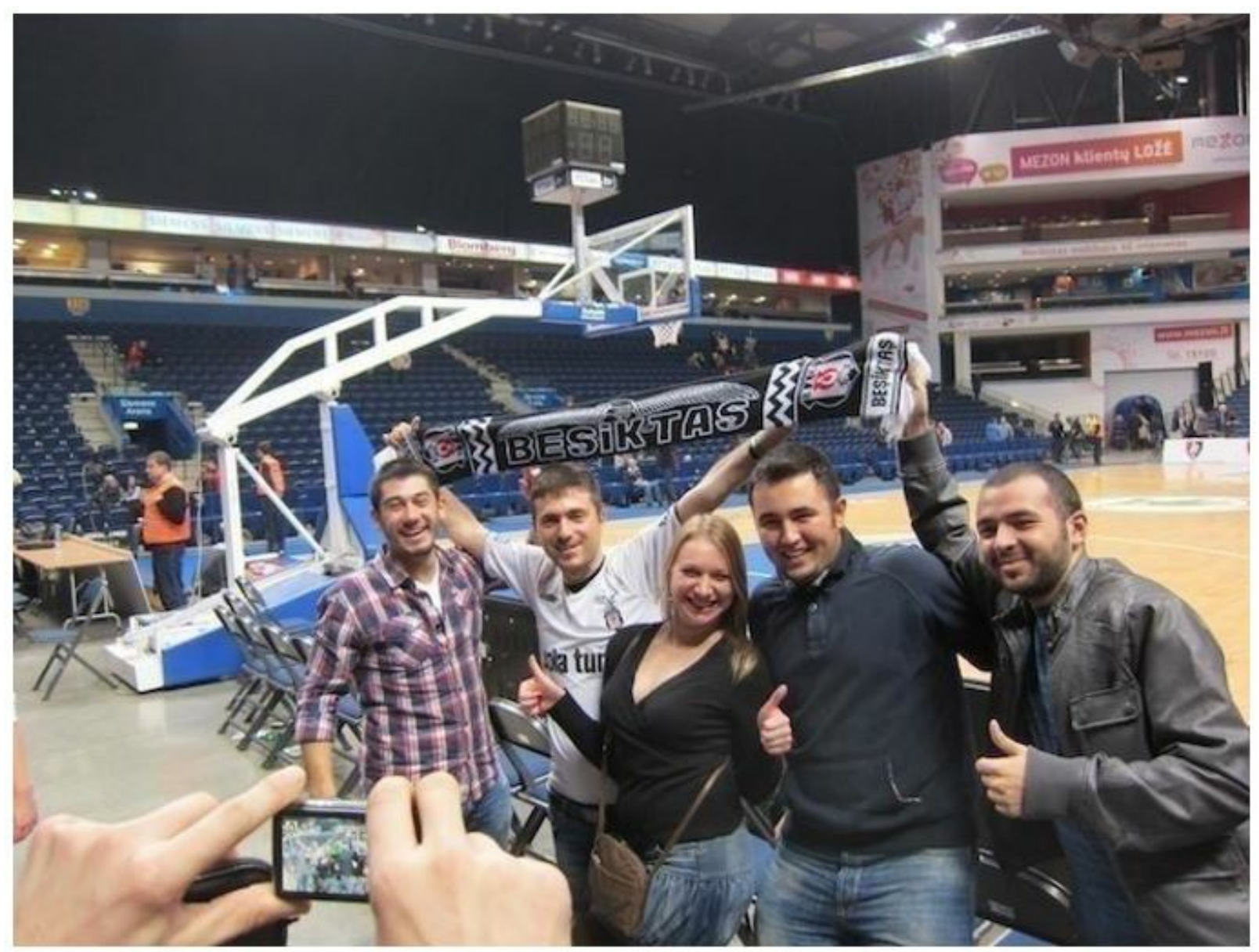

Figure 3. Lietuvos Rytas fan interposing herself for a photograph amongst a group of Beşiktaş fans, Vilnius, Lithuania 8 November 2012 (author's photo).

\section{Disputed Banners}

7.1 A further ethnographic example will help explain better the process of using banners - both physical and mediatised - for positioning oneself within the topography of fandom. In September 2012 a group of 50 or so Beşiktaş fans from Nuremberg in Germany formed a Nurnberg Beşiktaş fan club (Nürnberg Beşiktaşhlar Derneği) to much fanfare. By April 2013 there had been a falling out and fifteen or so members of the collective left to set up their own rival group, called Nürnberg Barikat (Nuremberg Barricade). This split required a reshaping of many landscapes, the first of which was the location where fans would watch games. My contacts were part of the group that split away under the Barikat name. In April 2013, unaware of the split I stopped in Nuremburg on an unscheduled visit. Instead of going to the old clubhouse, I was taken to a bar owned by a Turkish speaker in his late 50 s to watch that evening's Beşiktaş match. On the way, we stop at a fan's house in order for him to get the banner of the new group.

The banner consisted of black and red spray-paint on a cotton sheet and reads Barikat (Barricade). Like with the Çarşı Londra banner, the two letter 'A's are stylised as the anarchist A, referencing again the main 'Çarşı' fan group in Turkey. I am told how the banner is itself inculcated in the dispute. 'We stole it from the dernek! [official fanclub]' says one fan. 'Who stole it?!' retorts another, objecting to the use of the word 'steal'. 'That's what they're saying about us!' responds the first. Those in the Barikat group feel it is their property anyway.

7.3 At half time in the football match, one of the group marshals everyone outside to be photographed alongside the banner. Once taken, the photo is uploaded to Facebook (fig. 4). Facebook has a number of mechanisms for giving feedback on a photograph. Within minutes, fans are posting comments underneath the image, clicking a button marked 'like', or using the 'poke' command to interact with users. ${ }^{[10]}$ These activities underscore how communicating on Facebook is an embodied, sensory-inscribed experience. Conventions in these new media spaces are based on a notion of space as a material element to be shaped, rather than an abstract symbol to be interpreted. When taken as a whole, the interaction of the fans generates a whirl of activity, an 'insistent, jerky nearness' of buttons flashing and comments updating that distracts and stimulates (Taussig 1991: 151). Interaction acts as a spur to further interaction as users are caught up in a loop of anticipation and fulfilment.

7.4 In such an environment miscued communication becomes more likely. Three days later, Mehmet[11], a member of the original Nurnberg group posts an angry comment under the photo, referring to the split and lambasting one fan in the photograph for his perceived duplicity. The rest of the Barikat group wade in, criticising the fan in turn by posting their own comments. The digital traces of the argument pile up one after the other. The 
fan is forced to delete his initial post and write another comment in apology. New spaces such as Facebook increase fans' ease of access to each other, but by the same token require an accumulation of new conventions and rules for reputation maintenance.

I would like to dwell on the form the critical comments take. The fan is attacked not for his opinion but for choosing the wrong medium in which to air it. The dispute that emerged in the flesh has transformed and transposed. It has multiplied from its origins, becoming mediated in activities such as banner pinching, and manifested in new places such as a catty exchange of comments on Facebook. Fans are distinguishing between these different mediums, which can also be thought of as different places, not out of a question of realness or 'authenticity' but appropriateness in the specific context. One commenter generates a hierarchy of mediums available to Mehmet ('If you believe what you said act like a man - we will meet and speak face to face. You know our phone numbers, our addresses!') suggesting that the one chosen was inferior to these other forms. Masculinity is pulled in, as speaking face to face is cast as 'acting like a man' and contrasted with 'pissy' commenting on Facebook (Face'de sallamaya olmuyor) ('If you have a problem, either come here or I will come to [your place] and we'll sort it. Don't be posting pissy remarks on Facebook'). Throughout, a continuity is assumed between online and offline personas. Practices are continuous with each other, wherever they take place, just as there is a continuity of 'thingness' behind the banner in its translations from physical object mediated in the flesh to a digital photograph being contested online.

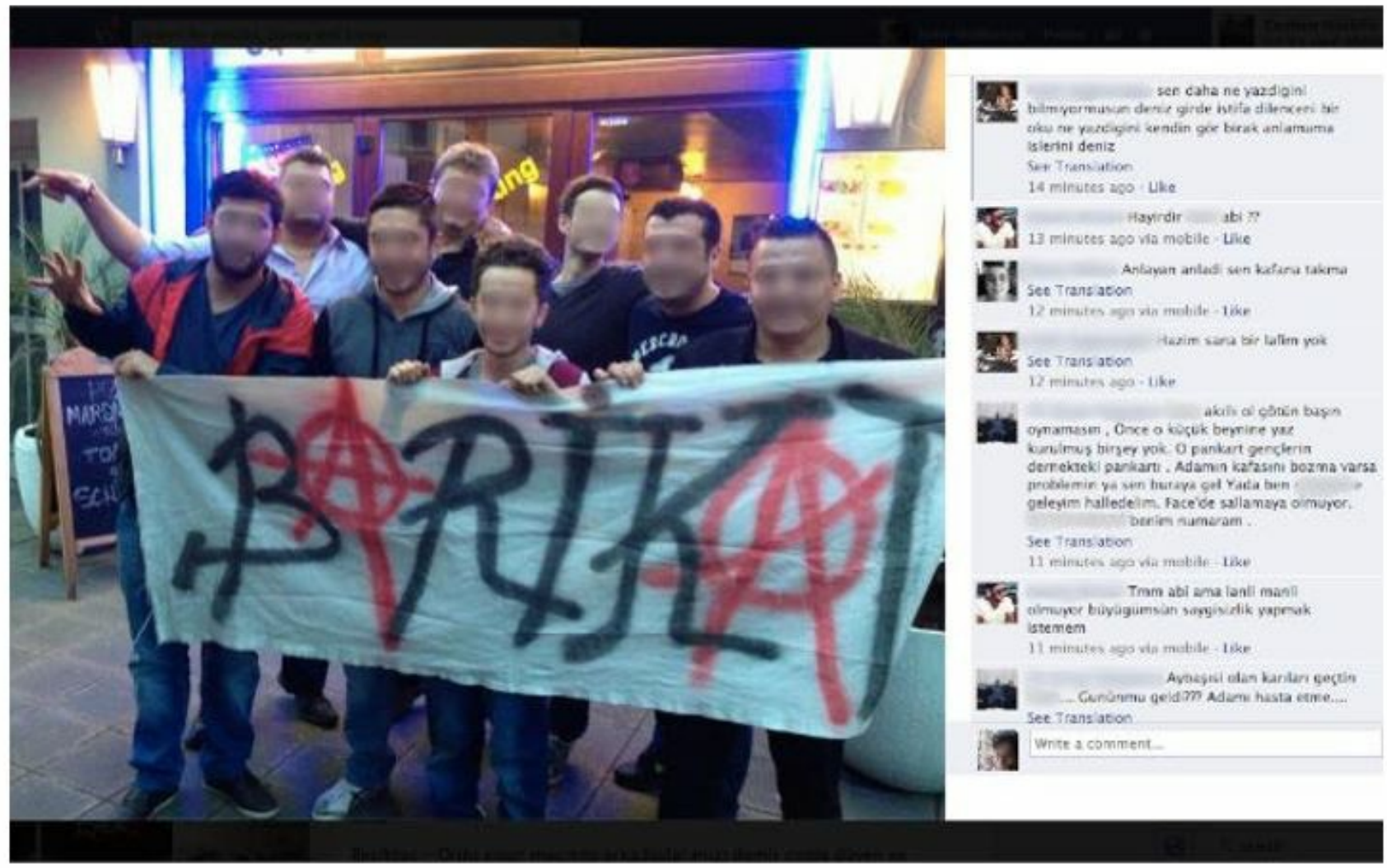

Figure 4. Facebook photograph of Nuremberg Barikat group with their banner (author's screenshot) ${ }^{[12]}$.

7.6 Following banners reveals some of the expanse of the football-supporting landscape that fans inhabit. The virtual spaces of the photograph and the Facebook page are new spaces in which banners can be used and communities built, yet they do not replace but augment. A sense of Beşiktaş community is generated across this plurality of places. As the banner circulates, it undergoes a continual shift in meaning. These shifts gesture towards what Nigel Thrift has termed the more 'performative political ecology' of the contemporary world. For Thrift, political experiment and invention has increased of late as groups 'make more room in the world for new political forms'. Groups produce new counter-publics and political forms through 'enigmatic bits of address and interpellation that disturb the social space' (Thrift 2008: 22).

7.7 For me, this describes well the banner: an object of enigmatic iconography, stitched together from a host of different sources and whose deployment disturbs space. Using them in stadiums, or outside clubs, taking pictures of them or pulling them into angry fights and arguments, all these practices disrupt existing configurations of fan community. In each movement is a positing of a new spatial and temporal arrangement, made possible by a virtual doubling of place. These processes generate a politics of 'effective togetherness', yet crucially one where no one is sure what they are gathering around. The points of unity are unstable, existing in one form before shifting.

\section{The default is distraction}




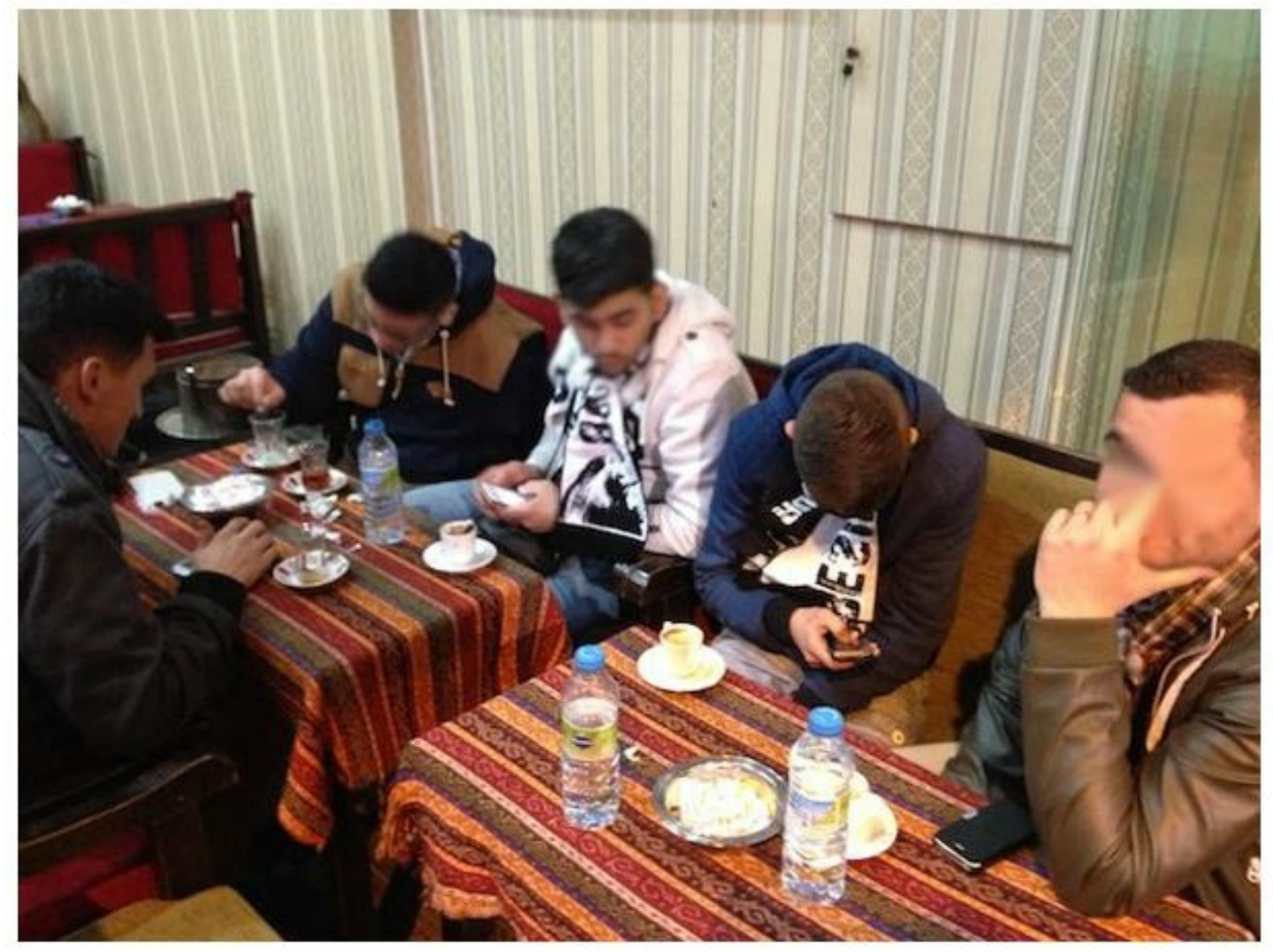

Figure 5. London Beşiktaş fans having a late-night coffee in Istanbul, Turkey.

8.1 Figure 5 is a picture from March 2013. Those present are Beşiktaş fans from London who are in Istanbul to attend the last big derby game of the season against local rivals Fenerbahçe. A close look reveals that everyone has a phone in front of them, and that no one is talking to anyone else. I do not wish to argue that this behaviour is inferior to past approaches to conversation - human beings have always reached for distractions to help them avoid the close proximity of face-to-face contact (see Parris 2013). Instead, I wish to suggest that the capabilities of the smartphone make this distraction more forceful and ubiquitous than previous strategies.

The forcefulness of smartphone distraction comes from its increasingly tactile nature. Walter Benjamin famously argued that the invention of the camera ushered in the era of 'mechanical reproduction', transforming notions of seeing and perceiving (Benjamin 1999). The anthropologist Michael Taussig builds on Benjamin to suggest that visual perception today has a material, tactile quality. For Taussig, the modern eye 'act[s] as conduit for our very bodies being absorbed by the filmic image'. Everyday knowledge comes not through reading the semiotics of a situation but through a form of touch, of proprioception and habitual tactility in the now-ness of things. Consequently Taussig suggests a new way of viewing experience: we should 'assume a distracted collective reading' of the everyday, what he calls 'by way of shorthand, a tactile eye' (Taussig 1991: 152).

His position is easier to substantiate at this particular historical juncture, courtesy of the ubiquity of interfaces that require from the user a very explicit tactile interaction. Foremost among these has been the touchscreen, an electronic display controlled through gestures of touch. Important, too, is the development of the vibrate function on mobile phones. Virtually all smartphones possess these two interfaces. Taken together, they point to how the phone has morphed to produce a more assaultive form of communication, discharging a haptic message via the pulsation in the pocket or the prod of the screen. ${ }^{[13]}$

If fans are increasingly interacting with each other via these devices, then fan socialisation is defined more and more by tactile distraction. Building a $21^{\text {st }}$ century transnational fan group involves laying claim to both virtual and physical spaces - the space of the phone screen and the space of the stadium - often simultaneously. There is a pluralisation of the spaces of performance, as visual, aural and digital fan practices the banner, the chant, and the Facebook comment - converge, interplay and intermingle with each other. Performing across such multiplicity is, ultimately, distracting. Nicholas Carr has demonstrated powerfully how diverting the effects of internet technologies can be in everyday life. The stream of virtual interactions interrupts one's physical movements, each action announces itself as a distracting beep or vibration, requiring the reallocation of one's attention and the delivery (or withholding) of a response. Over time, such habitual distraction rewires the cognitive process, altering notions of concentration, interaction and memory making (Carr 2011).

8.5 If habitual actions generate place, and those actions are best characterised by distraction, then perhaps the Beşiktaş places that come about through fan practices should be cast as 'distracting places' or 'places of 
distraction'. This suggestion in turn should prompt us to refigure the benchmarks by which we judge affective relations. Authors such as Carr, Taussig and Thrift have attempted to shift sociological paradigms to set greater importance on distracted interaction in the construction of selfhood (Carr 2011; Taussig 1991; Thrift 2008). The experiences of European Beşiktaş supporters reveal the need for scholars of football to contribute to the task. There has been increasing attention on the tight imbrication of the game with media practices, both new and old (see Krovel \& Roksvold 2012; Lash \& Lury 2007a; Rowe et al. 2010). I have attempted to show how this work can benefit from cross-pollination with wider debates surrounding the production of space and materiality of internet media. Comprehending the workings of current fan communities requires multiple conceptual lenses, differing field sites and sensitivity for the bodily and sensory dimensions of the experience. The 'tactile eye' bores deep.

\section{Conclusion}

9.1 This essay has been an exploration of how internet media impact upon the generation of a transnational fan community. Following the traces of two items - the production and display of banners and singing of chants - we glimpse how these two historic elements of football support have become 'mediatised' in $21^{\text {st }}$ century fandom. Virtual spaces have become the sites where items are more frequently used, where the aural, visual and digital all come together. For many overseas fans, the Facebook News Feed ${ }^{[14]}$ has supplanted the terrace as the realm in which they are more adept and at ease with negotiating practices of belonging.

The move is not one from material to representation, as media itself is fundamentally experienced as a 'thing', a tactile object experienced through swipes, pokes and prods which affects viscerally. Media use should be characteristed as haptic, and media environments understood as inhabited according to 'traditional spatial sensibilities' (DeNicola 2012) as ideas of how a banner should be hung in a stadium affect how it is to be photographed for Facebook. The intermeshing of new media practices with the old is less one of studied contemplation and more a distracted utilisation of the affordances of the medium at hand, whether in the stadium, on Facebook or at work.

By expanding the range of spaces in which one can be a fan, Internet media have ultimately made the generation of a European Beşiktaş fan community a more stressful and contested process. Speaking of how committed European Beşiktaş fans followed the team in a pre-internet age, a fan in his forties states: 'everyone went to Beşiktaş matches by themselves... just 2, 3 people in a car. There wasn't a fan group... everyone went by themselves, with their own friends or family.'[15] By contrast, the devoted contemporary fan not only has to be physically there at games but also virtually present in fan interactions on Facebook, debates on fan message boards or virtualised chants played on one's smartphone.

9.4 The literature on transnational football fandom has rightly highlighted how internet media provide fans at a distance with more ways to intervene successfully into the fan community (Ruddock et al., 2010). Yet this argument has perhaps been overstated through greater concentration on those supporters who are more transient or 'cool' in their association, such as the 'flaneur' (Giulianotti 2002) or 'satellite fan' (quoted in Millward 2011: 80). For the committed overseas fan who attends games anyway, such as the Beşiktaş interlocutors who comprise this piece, the growth of virtual space simply elongates the chains of requirements that need to be fulfilled.

9.5 In this regard, and as Millward (2011) has argued, perhaps the supporting practices of transnational supporters are not as far removed from the 'local' fan as first imagined. They mirror each other not only in how authenticity is gleaned but also in the stress and contestation of occupying simultaneously multiple virtual and actual spaces. In $21^{\text {st }}$ century fandom, fans frequently feel a power in their 'togetherness', yet one that is hard to utilise, born as it is out of the distracted doing of diverse groupings of fans, spread across a city, continent and globe. Nigel Thrift asks, perhaps rhetorically, 'how is it possible...to group around states that are neither dependent on lasting objects nor on fixed locations?' (Thrift 2008: 22). The example of European Beşiktaş fans and the use of their chants and banners shows ethnographically how difficult and contested this process can be.

\section{Notes}

Tagging is a common activity in computing where you add a character to a piece of data in order to identify it. On Facebook, this takes the form of associating a person's name with the posting of a comment or, in this instance, an image.

For a history of migration from Turkey to Europe see Mandel 2008.

The role of non-internet media in the generation of community has been a topic of scholarly attention for some time. The most influential is probably Benedict Anderson's study of how "print capitalism" generates the community of nation (Anderson 2006). Yet there have been a host of important studies, investigating media communication practices from photographs (Pinney 1997; Strassler 2010) to television (Abu-Lughod 2004) to telephony (Horst \& Miller 2006). 
calling and assembling of people (Latour 2005).

Associations of fixity perhaps derive from the strong influence of Heidigger's notion of Wohnen (beingat-home) on the academic study of habitation and dwelling (see Heidegger 1927; and Moores 2012).

For more comprehensive definition of the smartphone see (Raento Oulasvirta, \& Eagle 2009).

This argument owes much to the philosophy of Gilles Deleuze. See Deleuze 2002, Deleuze \& Guattari 2004; and Massumi 2002.

See Candan \& Kolluoğlu 2008; Low 2003; Sheller 2004.

The game took place in December 2011, when fallout from the Mavi Marmara incident had led to a souring of relations between Turkey and Israel. The Mavi Marmara was one of a fleet of ships that set sail from Turkey for the Gaza Strip on $30^{\text {th }}$ May 2010, in an attempt to break the blockade on the enclave by Israel. The boats were boarded by the Israeli army in open sea, and 9 activists killed. Relations only improved when Israeli Prime Minister Benjamin Netanyahu formally apologized in March 2013.

The like button allows the user to give positive feedback on a posting without leaving a comment. The button contains the graphic of a hand with its thumb raised. The poke command is a gesture that allows the user to 'poke' another user. The purpose is deliberately ambiguous, although it is interpreted mostly as a way of saying hello or getting a user's attention.

All names have been altered to protect the privacy of my informants.

The image has been altered to protect the privacy of my informants.

Similar to a home page, the News Feed in Facebook displays a select snippet of what one's friends are up to, ordered according to time and importance.

For more on the increasingly haptic apprehension of space, see ( Thrift 2004).

Interview with the author, Nuremberg, 27 April 2013.

\section{References}

ABU-LUGHOD, L. (2004). Dramas of Nationhood: The Politics of Television in Egypt. Chicago and London: University of Chicago Press. [doi://dx.doi.org/10.7208/chicago/9780226001982.001.0001]

ANDERSON, B. (2006). Imagined Communities: Reflections on the Origin and Spread of Nationalism. London: Verso.

APPADURAI, A. (Ed.). (1986). The Social Life of Things: Commodities in Cultural Perspective. Cambridge: Cambridge University Press. [doi://dx.doi.org/10.1017/CBO9780511819582]

BEN PORAT, A. (2000). Overseas Sweetheart: Israelis Fans of English Football. Journal of Sport and Social Issues, 24(4), p. 344-350. [doi://dx.doi.org/10.1177/0193723500244003]

BENJAMIN, W. (1999). The Work of Art in The Age of Mechanical Reproduction. In Hannah Arendt (Ed.), W. Benjamin, Illuminations. London: Pimlico.

BOELLSTORFF, T. (2008). Coming of Age in Second Life: An Anthropologist Explores the Virtually Human . Oxford: Princeton University Press.

BOURDIEU, P. (1993). Outline of a Theory of Practice. (R. Nice, Trans.). Cambridge: Cambridge University Press.

CANDAN, A. B., \& Kolluoğlu, B. (2008). Emerging Spaces of Neoliberalism: A Gated Town and a Public Housing Project in Istanbul. New Perspectives on Turkey, 39, p. 5-46.

CARR, N. (2011). The Shallows: How the Internet is Changing the Way We Think, Read and Remember . London: Atlantic.

CHAMBERS, I. (1994). The Aural Walk. In Migrancy, Culture, Identity London and New York: Routledge. p. 4953 .

COLEMAN, E. G. (2012). Coding Freedom: The Ethics and Aesthetics of Hacking. Princeton, NJ: Princeton University Press. 
DELEUZE, Gilles. (2002) "The Actual and the Virtual." In Dialogues II, by Gilles Deleuze and Claire Parnet, p. 148-52. translated by Eliot Ross Albert. New York: Columbia University Press.

DELEUZE, Gilles, \& Felix Guattari (2004) A Thousand Plateaus: Capitalism and Schizophrenia . London: Continuum.

DENICOLA, L. (2012). Geomedia: The Reassertion of Space within Digital Culture. In H. A. Horst \& D. Miller (Eds.), Digital Anthropology p. 80-98. London and New York: Berg.

FARMAN, J. (2012). Mobile Interface Theory: Embodied Space and Locative Media. London: Routledge.

GELL, A. (1998). Art and Agency: An Anthropological Theory. Oxford: Oxford University Press.

GIBBONS, T., \& Dixon, K. (2010). Surf's Up! A Call to Take English Soccer Fan Interactions on the Internet More Seriously. Soccer and Society, 11(5), p. 599-613. [doi://dx.doi.org/10.1080/14660970.2010.497359]

GIULIANOTTI, R. (2002). Supporters, Followers, Fans, and Flaneurs: A Taxonomy of Spectator Identities in Football. Journal of Sport and Social Issues, 26(1), p. 25-46.

[doi://dx.doi.org/10.1177/0193723502261003]

GIULIANOTTI, R., \& Robertson, R. (2006). Glocalization, Globalization and Migration: The Case of Scottish Football Supporters in North America. International Sociology, 21(2), p. 171-198. [doi://dx.doi.org/10.1177/0268580906061374]

GIULIANOTTI, R., \& Robertson, R. (2007). Forms of Globcalization: Globalization and the Migration Strategies of Scottish Football Fans in North America. Sociology, 41(1), p. 133-152. [doi://dx.doi.org/10.1177/0038038507073044]

GIULIANOTTI, R., \& Robertson, R. (2009). Globalization and Football. London: Sage.

HAND, M. (2012). Ubiquitous Photography. Cambridge: Polity.

HEIDEGGER, M. (1927). Being and Time. (J. Stambaugh, Trans.). New York: SUNY Press.

HOGNESTAD, H. (2006). Transnational Passions - A Statistical Study of Norwegian Football Fans. Soccer and Society, 7(4), p. 439-462. [doi://dx.doi.org/10.1080/14660970600905737]

HOGNESTAD, H. (2009). Transglobal Scandinavian Globalization and the Contestation of Identities in Football. Soccer and Society, 10(3-4), p. 358-373. [doi://dx.doi.org/10.1080/14660970902771423]

HORST, H., \& Miller, D. (2006). The Cell Phone: An Anthropology of Communication. New York: Berg.

ITO, M., Matsuda, M., \& Okabe, D. (Eds.). (2005). Persona, Portable, Pedestrian: Mobile Phones in Japanese Life. Cambridge, MA: MIT Press.

ITO, M., Okabe, D., \& Anderson, K. (2009). Portable Objects in Three Global Cities: The Personalization of Urban Places. In R. Ling \& S. W. Campbell (Eds.), The Reconstruction of Space and Time: Mobile Communication Practices New Brunswick, NJ and London: Transaction Publishers. p. 67-87.

KROVEL, R., \& Roksvold, T. (Eds.). (2012). We Love to Hate Each Other: Mediated Football Fan Culture. Gothenburg: Nordicom.

LASH, S., \& Lury, C. (2007a). Football Biography: Branding the Event. In Global Culture Industry: The Mediation of Things (p. 39-64). Cambridge: Polity.

LASH, S., \& Lury, C. (2007b). Global Culture Industry: The Mediation of Things. Cambridge: Polity.

LATOUR, B. (2005). Reassembling the Social: An Introduction to Actor-Network-Theory . Oxford: Oxford University Press.

LEFEBVRE, H. (1991). The Production of Space. (D. Nicholson-Smith, Trans.). Oxford: Blackwell Publishing.

LING, R., \& Donner, J. (2009). Mobile Phones and Mobile Communication. Cambridge: Polity.

LOW, S. M. (2003). Behind the Gates: Life, Security, and the Pursuit of Happiness in Fortress America . London: Routledge.

MANDEL, R. (2008). Cosmopolitan Anxieties: Turkish Challenges to Citizenship and Belonging in Germany . London: Duke University Press. [doi://dx.doi.org/10.1215/9780822389026]

MARCUS, G. (1995). Ethnography in/of the World System: The Emergence of Multi-Sited Ethnography. Annual Review of Anthropology, 24, p. 95-117. [doi://dx.doi.org/10.1146/annurev.an.24.100195.000523] 
MASSUMI, B. (2002) Parables for the Virtual: Movement, Affect, Sensation. Durham, NC and London: Duke University Press.

MAZZARELLA, W. (2004). Culture, Globalization, Mediation. Annual Review of Anthropology, 33, p. 345-367. [doi://dx.doi.org/10.1146/annurev.anthro.33.070203.143809]

MILLER, D. (Ed.). (2005). Materiality. London: Duke University Press. [doi://dx.doi.org/10.1215/9780822386711]

MILLER, D. (2011). Tales From Facebook. Cambridge: Polity.

MILLWARD, P. (2011). The Global Football League: Transnational Networks, Social Movements and Sport in the New Media Age. London: Palgrave MacMillan. [doi://dx.doi.org/10.1057/9780230348639]

MOORES, S. (2012). Media, Place \& Mobility. London: Palgrave MacMillan.

ORTNER, S. B. (2006). Anthropology and Social Theory: Culture, Power, and the Acting Subject. Durham, NC and London: Duke University Press. [doi://dx.doi.org/10.1215/9780822388456]

PARRIS, M. (2013, August 17). Conversation dies. Smartphone to the rescue | The Times. The Times (London). Retrieved from http://www.thetimes.co.uk/tto/opinion/columnists/matthewparris/article3845219.ece.

PINNEY, C. (1997). Camera Indica: The Social Life of Indian Photographs. Chicago and London: University of Chicago Press.

RAENTO, M., Oulasvirta, A., \& Eagle, N. (2009). Smartphones: An Emerging Tool for Social Scientists. Sociological Methods \& Research, 37(3), p. 426-454. [doi://dx.doi.org/10.1177/0049124108330005]

ROWE, D., Ruddock, A., \& Hutchins, B. (2010). Online Fan Message Boards and Networked Digital Media Sport Communities. Convergence: The International Journal of Research into New Media Technologies, 16(3), p. 298-315. [doi://dx.doi.org/10.1177/1354856510367622]

RUDDOCK, A., Hutchins, B., \& Rowe, D. (2010). Contradictions in Media Sport Culture: The Reinscription of Football Supporter Traditions Through Online Media. European Journal of Cultural Studies, 13(3), p. 323-339. [doi://dx.doi.org/10.1177/1367549410363200]

SCANNELL, P. (1996). Radio, Television and Modern Life: A Phenomenological Approach. Oxford: Blackwell.

SHELLER, M. (2004). Automotive Emotions: Feeling the Car. Theory, Culture, Society, 21(4-5), p. 221-242. [doi://dx.doi.org/10.1177/0263276404046068]

SHELLER, M., \& Urry, J. (2006). The New Mobilities Paradigm. Environment and Planning A, 38(2), p. 207226. [doi://dx.doi.org/10.1068/a37268]

STRASSLER, K. (2010). Refracted Visions: Popular Photography and National Modernity in Java . Durham, NC and London: Duke University Press. [doi://dx.doi.org/10.1215/9780822391548]

TAUSSIG, Mi. (1991). Tactility and Distraction. Cultural Anthropology, 6(2), p. 147-153.

[doi://dx.doi.org/10.1525/can.1991.6.2.02aooo20]

THRIFT, N. (2004). Movement-space: The Changing Domain of Thinking Resulting from the Development of New Kinds of Spatial Awareness. Economy and Society, 33(4), p. 582-604.

[doi://dx.doi.org/10.1080/0308514042000285305]

THRIFT, N. (2008). Non-Representational Theory: Space, Politics, Affect. London: Routledge.

THRIFT, N. (2011). Lifeworld Inc - and What to Do About it. Environment and Planning D: Society and Space, 29, p. 5-26. [doi://dx.doi.org/10.1068/do310] 